\section{Water Conservation, Growth, and Water Use Efficiency of Container- grown Woody Ornamentals Irrigated Based on Daily Water Use}

\author{
Aaron L. Warsaw ${ }^{1}$, R. Thomas Fernandez ${ }^{2,5}$, and Bert M. Cregg ${ }^{3}$ \\ Department of Horticulture, Plant and Soil Sciences Building, Michigan \\ State University, East Lansing, MI 48824
}

Jeffrey A. Andresen ${ }^{4}$

Department of Geography, 236 Geography Building, Michigan State

University, East Lansing, MI 48824

Additional index words. irrigation scheduling, nursery production, overhead irrigation, volumetric moisture content, crop coefficient

\begin{abstract}
Irrigation scheduling based on plant daily water use (DWU) to conserve water without adversely affecting plant growth compared with a traditional irrigation rate was investigated for 25 common container-grown woody ornamentals. Ten different taxa were grown in 2006 and 2007 and five in 2008 in 10.2-L (No. 3) containers. Overhead irrigation was applied in four treatments: 1$)$ a control irrigation rate of $19 \mathrm{~mm}(1.07 \mathrm{~L}$ per container) per application (control); 2) irrigation scheduled to replace $100 \% \mathrm{DWU}$ per application (100DWU); 3) irrigation alternating every other application with $100 \%$ replacement of DWU and 75\% DWU (100-75); and 4) irrigation scheduled on a three application cycle replacing $100 \%$ DWU followed by two applications of $75 \%$ DWU (10075-75). Irrigation applications were separated by at least $24 \mathrm{~h}$. Daily water use was calculated by measuring the difference in volumetric moisture content $1 \mathrm{~h}$ and approximately $24 \mathrm{~h}$ after irrigation. The three DWU treatments reduced total irrigation applied $6 \%$ to $75 \%$ compared with the control depending on treatment and species, except for Buddleja davidii 'Guinevere' in which total irrigation applied by the 100DWU, $100-75$, and $100-75-75$ treatments was $26 \%, 10 \%$, and $5 \%$, respectively, greater than the amount applied to the control. Final growth index [(plant height + width A + width B)/3] of all DWU treatments was greater than or equal to the control for all taxa. Forsythia xintermedia 'New Hampshire Gold', Hydrangea arborescens 'Dardom', Hydrangea paniculata 'Unique', and Weigela florida 'Wilma' had higher water use efficiencies (estimated as the change in growth index per liter of water applied) at lower irrigation treatment volumes with no differences in growth index or growth index increase, indicating that further irrigation reductions may be possible without affecting growth. PourThru electrical conductivity of $\boldsymbol{H}$. arborescens 'Dardom', Spiraea fritschiana 'Wilma', and Viburnum $\times$ burkwoodii 'Chenaultii' measured in 2007 did not accumulate to damaging levels. Final plant size of all taxa under DWU treatments was the same or greater than the control and substantially less water was applied under DWU treatments except for B. davidii 'Guinevere'.
\end{abstract}

\footnotetext{
Received for publication 10 Apr. 2009. Accepted for publication 26 May 2009.

This research was funded by Michigan State University Project GREEEN and the Michigan Department of Agriculture Horticultural Fund. Additional support provided by Spring Meadow Nursery, Inc. for supplying the plant material; Renewed Earth, Inc. for supplying potting substrate; and Harrell's, Inc. for supplying fertilizer.

The use of company or product names in this publication does not imply endorsement.

This paper is from a thesis submitted by the senior author in partial fulfillment of the requirements for the M.S. degree.

${ }^{1}$ Graduate Assistant, Department of Horticulture.

${ }^{2}$ Associate Professor, Department of Horticulture.

${ }^{3}$ Associate Professor, Departments of Horticulture and Forestry.

${ }^{4}$ Associate Professor, Department of Geography.

${ }^{5}$ To whom reprint requests should be addressed; e-mail fernan15@msu.edu.
}

Conserving water and reducing the environmental impact of runoff are two important issues presently confronting container nurseries. Current regulations and laws limit water consumption by container nurseries in California, Florida, North Carolina, Oregon, and Texas and nutrient management laws in Maryland, Delaware, and California limit nutrient concentrations in runoff (Beeson et al., 2004). Nurseries in close proximity to urban areas face increasing competition for ground and surface water resources. In some areas of Florida, permitted water allotments for nurseries have decreased by up to $40 \%$ over the past 12 years (Beeson et al., 2004). Given a likely increase in the cost of water, lower water availability, and increasingly stringent legislation, the development of irrigation scheduling practices that conserve water and reduce runoff without adversely affecting crop quality will be crucial for the future success of container nurseries.

Large quantities of runoff often results from poor irrigation efficiency with only $13 \%$ to $26 \%$ of applied overhead irrigation being retained in the container (Weatherspoon and Harrell, 1980). If not captured, water, fertilizers, and other agricultural chemicals can leave the production area and enter surrounding water resources with the potential for environmental contamination. One way to minimize runoff is to group plants with similar water requirements together and follow current recommended management practices that state irrigation volume should be based on the amount of water lost since the last irrigation (Michigan Department of Agriculture, 2009; Southern Nursery Association, 2007). Applying irrigation based on plant demand or daily water use (DWU) is a key concept in waterconserving irrigation scheduling.

Daily water use is the combined loss of water from plant transpiration and substrate evaporation (Tyler et al., 1996; Yeager, 2003). This type of irrigation scheduling requires that the DWU of the plant be known. However, scientific information regarding the water use of the thousands of species and cultivars of woody ornamentals currently grown is limited. One way to measure DWU of containergrown plants is by using soil moisture sensors (Cornejo et al., 2005; Garcia y Garcia et al., 2004). Quantifying the DWU of a wide range of container-grown woody ornamentals will allow various species and cultivars to be categorized by water use so those with similar water uses can be grouped together to minimize overwatering and excess runoff.

This experiment investigated whether irrigation scheduling at DWU or as a percentage of DWU could conserve water without negatively impacting plant growth compared with a traditional irrigation rate of $19 \mathrm{~mm}(1.07 \mathrm{~L}$ per container) per application. The objectives were to: 1) determine the effect of scheduling irrigation according to DWU on water conservation and plant growth; 2) determine DWU and water use efficiency (WUE) of several types of common container-grown woody ornamentals and classify them as low, moderate, or high water users; and 3) evaluate the effect of irrigation volume on substrate soluble salt levels.

\section{Materials and Methods}

Site specifications. The experiment was conducted at the Michigan State University Horticulture Teaching and Research Center (HTRC), Holt, MI (lat. $42.67^{\circ} \mathrm{N}$, long. $84.48^{\circ} \mathrm{E}$, elevation $264 \mathrm{~m}$ ). Twenty-five species of container-grown woody ornamentals, 10 different species in 2006 and 2007 and five in 2008, were grown on a site developed as an outdoor container nursery facility. The production surface consisted of limestone gravel covering a landscape fabric to suppress weed growth. Rainfall was recorded by a Michigan Automated Weather Network (MAWN) weather station located on-site at the HTRC. 
Plant material and culture. Plant species and cultivars used during each year are shown in Table 1. Plants were potted up from $5.7-\mathrm{cm}$ potted liners received from a commercial nursery (except Rosa 'Winnipeg Parks', which were $10-\mathrm{cm}$ potted liners) into 10.2-L (No. 3) containers from 6 to 9 Sept. 2005, from 5 to 8 Sept. 2006, and from 4 to 7 Sept. 2007. Container substrate consisted of $85 \%$ pine bark: $15 \%$ peatmoss (vol:vol) supplied by Renewed Earth, Inc. (Kalamazoo, MI). The air space, container capacity, and total porosity of the substrate were calculated to be $38 \%, 43 \%$, and $82 \%$, respectively. Except for Thuja plicata 'Atrovirens' in 2006 and Thuja occidentalis 'Techny' in 2007, plants were pruned to a uniform height and width on 6 June 2006, 21 May 2007, and 15 June 2008 before treatments began. Pruning of new growth involved removing less than one-third of the plant canopy.

Plants grown during the 2006 experiment were fertilized on 5 June 2006 with 26 g per container of a $17.0 \mathrm{~N}-3.5 \mathrm{P}-6.6 \mathrm{~K}$ controlledrelease fertilizer $(\mathrm{CRF})$ with micronutrients with a release period of 4 months at $27{ }^{\circ} \mathrm{C}$ (HFI Topdress Special; Harrell's Inc., Lakeland, FL). Plants grown during the 2007 experiment were fertilized on 14 May 2007 with $26 \mathrm{~g}$ per container of a $19.0 \mathrm{~N}-2.2 \mathrm{P}$ $7.5 \mathrm{~K}$ CRF with micronutrients with a release period of 3 to 4 months at $27{ }^{\circ} \mathrm{C}$ (HFI Topdress Special; Harrell's Inc.). For the 2008 experiment, plants were fertilized with $26 \mathrm{~g}$ per container of a $19.0 \mathrm{~N}-2.6 \mathrm{P}-10.0 \mathrm{~K}$ $\mathrm{CRF}$ with micronutrients with a release

Table 1. List of container-grown woody ornamentals used in the 2006, 2007, and 2008 experiments. 2006

Callicarpa dichotoma (Lour.) K. Koch 'Early Amethyst'

Cornus sericea (Michx. F.) L. 'Farrow' Deutzia gracilis Sieb. and Zucc. 'Duncan'

Kerria japonica (L.) DC. 'Albiflora'

Symphoricarpos $\times$ doorenbosii Krüssm. 'Kordes'

Syringa $\times$ hyacinthiflora (Lemoine) Rehd.

'Asessippi'

Syringa $\times$ prestoniae McKelv. 'Donald Wyman'

Thuja plicata D. Don. 'Atrovirens'

Viburnum dentatum L. 'Ralph Senior'

Viburnum opulus L. 'Roseum'

2007

Caryopteris $\times$ clandonensis A. Simmonds ex Redh. 'Dark Knight'

Cotinus coggygria Scop. 'Young Lady'

Forsythia $\times$ intermedia Zab.

'New Hampshire Gold'

Hydrangea arborescens L. 'Dardom'

Hydrangea paniculata Sieb. 'Unique'

Rosa L. 'Winnipeg Parks'

Spiraea fritschiana Schneid. 'Wilma'

Thuja occidentalis L. 'Techny'

Viburnum ×burkwoodii Burkw. and Skipw. 'Chenaultii'

Weigela florida (Bunge.) A. DC. 'Alexandra' 2008

Buddleja davidii Franch 'Guinevere'

Hydrangea serrata (Thunb.) Ser. 'Blue Billow' Lonicera korolkowii Stpf. 'Honey Rose'

Spiraea japonica L. 'Flaming Mound'

Viburnum nudum L. 'Bulk' period of 5 months at $27{ }^{\circ} \mathrm{C}$ (Acid Blend With Micros; Harrell's Inc.). Fertilizer applications were made based on label recommendations for No. 3 nursery containers. One application of Cygon 2-E Dimethoate [O, O-dimethyl- S-(N-methylcarbamoyl-methyl) phosphorodithioate] systemic insecticide was sprayed on plants at a rate of $1.17 \mathrm{~L} \cdot \mathrm{ha}^{-1}$ on 24 July 2006 for aphid control.

Experimental design. The experiment was a completely randomized design with six subsamples (individual plants) of each species per treatment replicate. The control treatment of $19 \mathrm{~mm}$ per application was chosen based on a survey of growers in the southeastern United States where growers replied that they normally watered for $\approx 1 \mathrm{~h}$ intending to apply $25 \mathrm{~mm} \cdot \mathrm{d}^{-1}$ of water (Fare et al., 1992) and from a study by Beeson (2006) who used a control treatment of $18 \mathrm{~mm} \cdot \mathrm{d}^{-1}$ to irrigate 11.4-L container-grown landscape shrubs. Plants received one of four irrigation treatments: 1) a control irrigation rate of $19 \mathrm{~mm}$ (1.07 L per container) per application (abbreviated as control); 2) irrigation scheduled to replace $100 \%$ DWU per application (100DWU); 3) alternating every other application with $100 \%$ DWU and $75 \%$ DWU (100-75); and 4) a three application cycle with one application of $100 \%$ DWU followed by two applications of 75\% DWU (100-7575). Irrigation applications were separated by at least $24 \mathrm{~h}$. Each irrigation treatment was replicated three times. During the 2006 experiment, irrigation treatments were applied daily from 14 June to 30 Sept. and every other day from 1 Oct. to 13 Oct. 2006. During 2007, irrigation treatments were applied daily from 8 June to 13 Oct. 2007. Irrigation treatments were applied daily from 28 June to 7 Oct. during the 2008 experiment.

Irrigation zones were $4.9 \mathrm{~m} \times 7.3 \mathrm{~m}$, each a treatment replicate. There were six plants of each species per treatment replicate. The six plants of the 10 species grown during 2006 and 2007 were randomly arranged in six rows of 10 spaced $45 \mathrm{~cm}$ on center within each treatment replicate. The six plants of the five species grown in 2008 were randomly arranged in five rows of six. Guard plants of the same age and container size bordered each treatment replicate on all sides to minimize edge effects. Species of guard plants varied, but order and arrangement of guard plants in all treatment replicates were identical. Plant canopies did interact with each other during the experiment, but the degree of interaction varied among treatment replicates depending on the species of each plant and the species surrounding that individual.

Daily water use. Daily water use was determined using a ThetaProbe Type ML2x soil moisture sensor (Delta-T Devices Ltd., Cambridge, U.K.) connected to a ThetaMeter Hand-Held Readout Unit Type HH1 (Delta-T Devices Ltd.). The sensing array of rods of the ThetaProbe is comprised of a $60-\mathrm{mm}$ long center rod with three additional $60-\mathrm{mm}$ rods equally spaced from the center rod forming a cylinder with a diameter of $\approx 30 \mathrm{~mm}$ (DeltaDevices Ltd., 1999). Measurement volume is within a $40 \mathrm{~mm}$ diameter $\times 60 \mathrm{~mm}$ long cylinder $\left(\approx 750 \mathrm{~mm}^{3}\right)$ surrounding the central rod (Delta-Devices Ltd., 1999). Volumetric moisture content was measured within the top $60 \mathrm{~mm}$ of the substrate surface by inserting the rods perpendicular to the substrate surface. Container height was $245 \mathrm{~mm}$. Volumetric moisture content of the container substrate of plants in control treatment replicates was measured $1 \mathrm{~h}$ after irrigation and before irrigation the next day. Daily water use was measured during 24-h periods without precipitation. The percent difference in volumetric moisture content was multiplied by the average volume of substrate $(9.7 \mathrm{~L}$ per container) to determine the volume of water lost from the container. A substrate-specific calibration was conducted to improve the accuracy of the ThetaProbe as outlined in the ThetaProbe Type ML2x user manual (Delta-T Devices Ltd., 1999). When using the substrate-specific calibration, the reported overall error of the ThetaProbe is \pm $0.01 \mathrm{~m}^{3} \cdot \mathrm{m}^{-3}$ (Delta-T Devices Ltd., 1999). Sampling errors are typically approximately $\pm 0.04 \mathrm{~m}^{3} \cdot \mathrm{m}^{-3}$ but may be as high as \pm 0.1 $\mathrm{m}^{3} \cdot \mathrm{m}^{-3}$ depending on the number of samples taken, substrate variability, and insertion errors (Delta-T Devices Ltd., 1999). Daily water use treatments were applied at the DWU from the most recent DWU measurement day until the next DWU measurement, approximately every 10 to $14 \mathrm{~d}$.

Irrigation application rate of the overhead system was determined by measuring the depth of water applied from three of the 12 irrigation zones (treatment replicates) before treatment initiation in 2006, 2007, and 2008 . Irrigation rate was measured using eight rain gauges randomly placed throughout each irrigation zone to collect water for $30 \mathrm{~min}$. The irrigation cycle was repeated with the eight rain gauges randomized again for a total of 16 measurements per irrigation zone. Irrigation application rates for the 2006, 2007, and 2008 experiments were $0.475 \mathrm{~mm} \cdot \mathrm{min}^{-1}$, $0.434 \mathrm{~mm} \cdot \mathrm{min}^{-1}$, and $0.99 \mathrm{~mm} \cdot \mathrm{min}^{-1}$, respectively. The higher application rate in 2008 was the result of the installation of new emitter heads and a new supply line in June 2008 that was required as a result of a drop in pressure in the former line and to maintain distribution uniformity greater than $80 \%$.

Irrigation applications. The source of irrigation water was a well, and irrigation applications were scheduled with a Rain Bird ESP-12LX Plus controller (Rain Bird Corporation, Azusa/Glendora, CA). Each treatment replicate was controlled by a $2.54-\mathrm{cm}$ Rain Bird 13DE04K solenoid valve (Rain Bird Corporation). Irrigation during 2006 and 2007 was applied through 12 Toro 570 Shrub Spray Sprinklers (The Toro Company, Riverside, CA) per treatment replicate. In 2008, new emitters (Hunter Pro nozzle fixed pattern emitters; Hunter Industries, Inc., San Marcos, CA) were installed. Emitters were mounted on 1.3-cm diameter risers at a height of 66 $\mathrm{cm}$. Emitter layout, regardless of manufacturer, consisted of two $360^{\circ}$ emitters, four $90^{\circ}$ emitters, and six $180^{\circ}$ emitters per treatment 
replicate, all with $2.44 \mathrm{~m}$ radius of coverage. Emitters were spaced $2.44 \mathrm{~m}$ apart in three rows of four with four $90^{\circ}$ emitters on the corners, six $180^{\circ}$ emitters along the edges, and two $360^{\circ}$ emitters in the middle of the block to provide head-to-head coverage. All irrigation was directed into the block.

Because there were multiple species in each treatment replicate, overhead irrigation was applied to DWU treatments at the rate of the species with the lowest DWU on each measurement day. For species with higher DWUs, additional water was applied by hand. Irrigation applications were scheduled to apply the correct volume based on irrigation rate and container surface area assuming $100 \%$ canopy penetration. Because of the large number of plants in the experiment and the time required to apply the DWU treatment irrigation volumes to each species by hand, DWU was measured from control plants so as not to interfere with the hand watering schedule. Irrigation was initiated between $0700 \mathrm{HR}$ and $0900 \mathrm{HR}$.

Data collection. Using a method similar to Knox (1989), plant water use efficiency was estimated in the current study by dividing the increase in growth index (GI) during the experiment by total water volume applied (irrigation plus precipitation; L per container). Plant response to irrigation treatments was evaluated by calculating plant GI every 2 to $4 \mathrm{wk}$ throughout the experiment and was calculated as [(plant width $\mathrm{A}+$ plant width perpendicular to plant width $\mathrm{A}+$ plant height)/3]. Plant height was measured from the container rim, and plant widths were measured perpendicular to each other at the same location on each measurement date.

During the 2007 experiment, PourThru electrical conductivity (EC) was measured with a Horiba Cardy Twin EC Meter (Spectrum Technologies, Inc., Plainfield, IL) using the PourThru extraction procedure as described by Bilderback (2001). Measurements were made $1 \mathrm{~h}$ after irrigation. PourThru EC was measured once during June, July, August, and September for all plants of $H$. arborescens 'Dardom', S. fritschiana 'Wilma', and V. ×burkwoodii 'Chenaultii', which were predicted to be high, moderate, and low water users, respectively.

Still and Davies (1993) classified containergrown woody ornamentals as heavy, moderate, or light water users based on total water consumption. Grouping species into similar water use classifications was an objective of the current study. Species in the current study were classified as high, moderate, or low water users by estimating a crop coefficient $\left(\mathrm{K}_{\mathrm{C}}\right)$ for the time period of the experiment (Table 2). Crop coefficient is the ratio of evapotranspiration of a specific crop $\left(\mathrm{ET}_{\mathrm{A}}\right)$ to the potential evapotranspiration $\left(\mathrm{ET}_{\mathrm{P}}\right.$; Dooenbos and Pruitt, 1975). Crop coefficients were estimated by dividing the total irrigation applied by the $100 \%$ DWU treatment by cumulative reference potential evapotranspiration. Reference potential evapotranspiration was estimated with the modified Penman method according to Kincaid and

Table 2. Average irrigation applied to container-grown woody ornamentals in 10.2-L containers under four irrigation treatments. ${ }^{z}$

\begin{tabular}{|c|c|c|c|c|c|}
\hline \multirow[b]{2}{*}{ Taxa } & \multicolumn{5}{|c|}{ Avg irrigation applied (mm per application) } \\
\hline & Control $^{\mathrm{y}}$ & 100DWU & $100-75$ & $100-75-75$ & $\mathrm{~K}_{\mathrm{C}}$ \\
\hline \multicolumn{6}{|l|}{2006} \\
\hline Callicarpa dichotoma 'Early Amethyst' & $19 \mathrm{a}^{\mathrm{x}}$ & $13.7 \mathrm{~b}$ & $12.0 \mathrm{bc}$ & $11.4 \mathrm{c}$ & 3.8 \\
\hline Cornus sericea 'Farrow' & $19 \mathrm{a}$ & $12.0 \mathrm{~b}$ & $10.5 \mathrm{c}$ & $10.0 \mathrm{c}$ & 3.4 \\
\hline Viburnum opulus 'Roseum' & $19 \mathrm{a}$ & $7.9 \mathrm{~b}$ & $6.9 \mathrm{c}$ & $6.6 \mathrm{c}$ & 2.2 \\
\hline Symphoricarpos $\times$ doorenbosii 'Kordes' & $19 \mathrm{a}$ & $7.4 \mathrm{~b}$ & $6.6 \mathrm{c}$ & $6.3 \mathrm{c}$ & 2.1 \\
\hline Syringa $\times$ hyacinthiflora 'Asessippi' & $19 \mathrm{a}$ & $6.8 \mathrm{~b}$ & $5.9 \mathrm{c}$ & $5.7 \mathrm{c}$ & 1.9 \\
\hline Kerria japonica 'Albiflora' & $19 \mathrm{a}$ & $6.8 \mathrm{~b}$ & $5.9 \mathrm{c}$ & $5.6 \mathrm{c}$ & 1.9 \\
\hline Thuja plicata 'Atrovirens' & $19 \mathrm{a}$ & $6.0 \mathrm{~b}$ & $5.2 \mathrm{bc}$ & $5.0 \mathrm{c}$ & 1.7 \\
\hline Viburnum dentatum 'Ralph Senior' & $19 \mathrm{a}$ & $5.8 \mathrm{~b}$ & $5.1 \mathrm{c}$ & $4.9 \mathrm{c}$ & 1.6 \\
\hline Deutzia gracilis 'Duncan' & $19 \mathrm{a}$ & $5.7 \mathrm{~b}$ & $5.0 \mathrm{c}$ & $4.7 \mathrm{c}$ & 1.6 \\
\hline \multicolumn{6}{|l|}{2007} \\
\hline Caryopteris $\times$ clandonensis 'Dark Knight' & $19 \mathrm{a}$ & $14.0 \mathrm{~b}$ & $12.3 \mathrm{c}$ & $11.7 \mathrm{c}$ & 3.7 \\
\hline Hydrangea paniculata 'Unique' & $19 \mathrm{a}$ & $13.9 \mathrm{~b}$ & $12.1 \mathrm{c}$ & $11.6 \mathrm{c}$ & 3.6 \\
\hline Forsythia $\times$ intermedia 'New Hampshire Gold' & $19 \mathrm{a}$ & $13.7 \mathrm{~b}$ & $12.1 \mathrm{c}$ & $11.5 \mathrm{c}$ & 3.6 \\
\hline Spiraea fritschiana 'Wilma' & $19 \mathrm{a}$ & $13.7 \mathrm{~b}$ & $12.0 \mathrm{c}$ & $11.4 \mathrm{c}$ & 3.6 \\
\hline Weigela florida 'Alexandra' & $19 \mathrm{a}$ & $13.7 \mathrm{~b}$ & $12.0 \mathrm{c}$ & $11.4 \mathrm{c}$ & 3.6 \\
\hline Hydrangea arborescens 'Dardom' & $19 \mathrm{a}$ & $11.5 \mathrm{~b}$ & $10.0 \mathrm{c}$ & $9.6 \mathrm{c}$ & 3.0 \\
\hline Rosa 'Winnipeg Parks' & $19 \mathrm{a}$ & $10.0 \mathrm{~b}$ & $8.8 \mathrm{c}$ & $8.4 \mathrm{c}$ & 2.6 \\
\hline Thuja occidentalis 'Techny' & $19 \mathrm{a}$ & $9.8 \mathrm{~b}$ & $8.6 \mathrm{c}$ & $8.2 \mathrm{c}$ & 2.6 \\
\hline Cotinus coggygria 'Young Lady' & $19 \mathrm{a}$ & $8.3 \mathrm{~b}$ & $7.3 \mathrm{c}$ & $6.9 \mathrm{c}$ & 2.2 \\
\hline Viburnum $\times$ burkwoodii 'Chenaultii' & $19 \mathrm{a}$ & $6.1 \mathrm{~b}$ & $5.4 \mathrm{bc}$ & $5.1 \mathrm{c}$ & 1.6 \\
\hline \multicolumn{6}{|l|}{2008} \\
\hline Buddleja davidii 'Guinevere' & $19 \mathrm{~b}$ & $24.0 \mathrm{a}$ & $21.0 \mathrm{~b}$ & $20.0 \mathrm{~b}$ & 6.8 \\
\hline Spiraea japonica 'Flaming Mound' & $19 \mathrm{a}$ & $17.8 \mathrm{a}$ & $15.5 \mathrm{~b}$ & $14.8 \mathrm{~b}$ & 5.0 \\
\hline Viburnum nudum 'Bulk' & $19 \mathrm{a}$ & $12.2 \mathrm{~b}$ & $10.7 \mathrm{c}$ & $10.2 \mathrm{c}$ & 3.4 \\
\hline Lonicera korolkowii 'Honey Rose' & $19 \mathrm{a}$ & $11.7 \mathrm{~b}$ & $10.2 \mathrm{c}$ & $9.7 \mathrm{c}$ & 3.3 \\
\hline Hydrangea serrata 'Blue Billow' & $19 \mathrm{a}$ & $11.0 \mathrm{~b}$ & $9.6 \mathrm{c}$ & $9.1 \mathrm{c}$ & 3.1 \\
\hline
\end{tabular}

${ }^{2}$ There were 110,128, and 102 irrigation applications during the 2006, 2007, and 2008 experiments, respectively. Total irrigation applied to each taxa of the $100 \%$ DWU treatment was divided by cumulative potential evapotranspiration during the experiment to estimate crop coefficients $\left(\mathrm{K}_{\mathrm{C}}\right)$ of each taxa. Cumulative potential evapotranspiration during 2006, 2007, and 2008 experiments was 394, 490, and 361 $\mathrm{mm}$, respectively. Low, moderate, and high water users correspond to $\mathrm{K}_{\mathrm{C}}<2,2 \leq \mathrm{K}_{\mathrm{C}}<3$, and $\mathrm{K}_{\mathrm{C}} \geq 3$. Treatments: Control $=19 \mathrm{~mm}$ per application; $100 \mathrm{DWU}=100 \%$ daily water use (DWU) each application; 100-75 = two-application cycle with 100\% DWU first application and 75\% DWU second application; 100 $75-75=$ three-application cycle $100 \%$ DWU first application followed by two applications of $75 \%$ DWU. Irrigation applications were separated by $\approx 24 \mathrm{~h}$.

${ }^{x}$ Means within same row with the same letter are not significantly different. Means separated by Tukey's honestly significance test $(\alpha=0.05)$.

Heerman (1974) from data obtained from a MAWN weather station located on-site.

Statistical analysis. Growth index and leachate EC data were analyzed for each species separately as repeated measures using PROC MIXED procedure of Statistical Analysis Software (SAS Version 9.1; SAS Institute, Cary, NC). When significant at the 0.05 level, treatment means on each measurement day were separated using a $t$ test in the PDIFF option of the LSMEANS statement and the SLICING option of PROC MIXED ( $\alpha=$ 0.05 ). Water use data and estimates of water use efficiency were subjected to analysis of variance using PROC GLM procedure of SAS and when significant $(\alpha=0.05)$, means were separated by Tukey's honestly significance test at the 0.05 level.

\section{Results and Discussion}

Water use 2006. Total irrigation applied to the control treatment during the 110 irrigation applications of the 122-d season was $2095 \mathrm{~mm}$ (117 L per container). Total rainfall during this period was $343 \mathrm{~mm}$ and resulted in the addition of 19 L per container (Fig. 1A). Irrigation was not applied when rainfall exceeded $20 \mathrm{~mm}$ during a 24-h period, which occurred six times during 2006 (Fig. 1A).
Data for Syringa xprestoniae 'Donald Wyman' is not presented because stunted growth and burning of leaf margins in all treatments resulted in a negative GI during the season. These effects were probably the result of factors that occurred before receiving the liners.

Daily water use was measured eight times during 2006 for all species except $C$. sericea 'Farrow', which was measured an additional day 1 week after the Day 58 DWU measurement because of dry substrate in the three DWU treatments. Flagging did not occur and the dry substrate could have been the result of a change in growth pattern during this time. During 2006, DWU slightly increased during the middle of the season with a peak on Day 39 (22 July 2006) for the majority of taxa (Fig. 2). Plant GI is also shown on Figure 2 to simplify presentation of relationships between water use and plant growth. General patterns of water use and GI are discussed after presentation of GI data. Daily water use of C. dichotoma 'Early Amethyst' and C. sericea 'Farrow' appeared generally higher than the other species in 2006 with DWU during the middle of the season exceeding or approaching the control treatment (Fig. 2A-B). Daily water use of $C$. dichotoma 'Early Amethyst' more than doubled from Day 24 to Day 


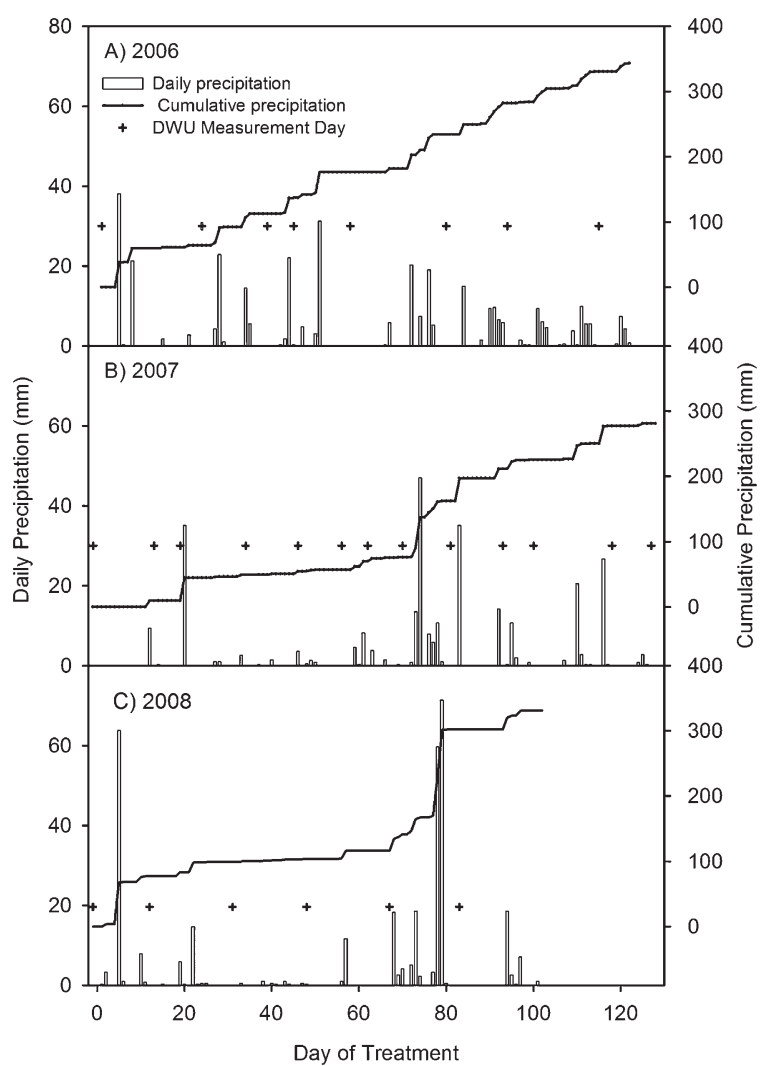

Fig. 1. Daily (vertical bars) and cumulative precipitation (line) for (A) 2006, Day $0=14$ June; (B) 2007, Day $0=7$ June; and (C) 2008, Day $0=27$ June. Crosshairs indicate day of daily water use (DWU) measurement. Data recorded at a Michigan Automated Weather Network (MAWN) weather station at the Michigan State University Horticulture and Teaching Research Center. Data courtesy of Michigan State University and the Enviro-weather project.

39 and then slowly decreased before a large drop during the 2-week period from Day 80 until Day 94 (Fig. 2A). Daily water use of $C$. sericea 'Farrow' peaked twice during the experiment on Days 39 and 65 (Fig. 2B). C. dichotoma 'Early Amethyst' was the only species to have a DWU higher than the control during 2006 (Fig. 2A). This occurred on Days 39,45 , and 58 when DWU was 23, 22, and $20 \mathrm{~mm}$, respectively. Day 39 had the highest or one of the highest DWU for all species (Fig. 2A-I). Lowest DWU was on Day 115 for all species except $V$. opulus 'Roseum', which occurred on Day 94 (Fig. 2A-I).

Average daily irrigation applied to the 100DWU, $100-75$, and 100-75-75 treatments ranged from $27 \%$ to $70 \%, 37 \%$ to $74 \%$, and $40 \%$ to $75 \%$, respectively, less than the control treatment depending on species (Table 2 ). Average irrigation applied to the 100-75 and 100-75-75 treatments was lower than the 100DWU treatment, except for $C$. dichotoma 'Early Amethyst' and T. plicata 'Atrovirens' in which there was no difference between the 100-75 and 100DWU treatments (Table 2). Average irrigation applied to the 100-75 and 100-75-75 treatments was $12 \%$ and $17 \%$ lower, respectively, than the $100 \mathrm{DWU}$ treatment.

Water use 2007. Total irrigation applied to the control treatment during the 128 irrigation applications of the season was $2438 \mathrm{~mm}$ (137 L per container). Total rainfall during this period was $281 \mathrm{~mm}$ and added $16 \mathrm{~L}$ per container (Fig. 1B). Irrigation was not applied when rainfall exceeded $20 \mathrm{~mm}$ during a 24-h period, which occurred five times during the experiment in 2007 (Fig. 1B).

Daily water use was measured on $13 \mathrm{~d}$ during the 2007 experiment. Daily water use of most taxa gradually increased during the first half of the experiment before gradually declining during the second half (Fig. 3A-J). Daily water use for most taxa peaked on Day 56 (2 Aug. 2007), which was later in the growing season than in 2006 (22 July). Daily water use was generally higher for taxa grown in 2007 with five taxa having DWU values that exceeded the control compared with only one taxon in 2006 (Figs. 2A and $3 \mathrm{~A}, \mathrm{C}, \mathrm{E}, \mathrm{G}$, and J). Daily water use exceeded the control for $C$. $\times$ clandonensis 'Dark Knight' on Days 13 and 56, F. xintermedia 'New Hampshire Gold' on Day 56, $H$. paniculata 'Unique' on Days 56 and 62, S. fritschiana 'Wilma' on Days 46 and 56, and $W$. florida 'Alexandra' on Days 56 and 62 (Fig. 3A, C, E, G, and J). Although different taxa were grown in 2006 and 2007, higher DWU during 2007 was likely caused by fewer precipitation events and amounts in 2007 (Fig. 1A-B) and higher evaporative demand on DWU measurement days in 2007 compared with 2006 (Fig. 4). Daily water use on Day 56 was highest or one of the highest water use days for all species in 2007 except $V$. $\times$ burkwoodii 'Chenaultii' on Day 13 (Fig. 3A-J). Daily water use on Day 127 was the lowest or among the lowest water use days for all species (Fig. 3A-J).

Average daily irrigation applied to the 100DWU, 100-75, and 100-75-75 treatments ranged from $27 \%$ to $68 \%, 36 \%$ to $72 \%$, and $39 \%$ to $73 \%$, respectively, less than the control depending on species (Table 2). These results were nearly identical to those in 2006 (Table 2). Average irrigation applied to the 100-75 and 100-75-75 treatments was lower than the 100DWU treatment for all species except $V$. $\times$ burkwoodii 'Chenaultii' in which there was no difference between the 100-75 and 100DWU treatments (Table 2). Average irrigation applied by the $100-75$ and $100-75-75$ treatments was $12 \%$ and $17 \%$ lower, respectively, than the 100DWU treatment, the same as in 2006.

Water use 2008. Total irrigation applied to the control treatment during the 102 irrigation applications of the season was 1943 mm (109 L per container). Total rainfall during this period was $341 \mathrm{~mm}$ and resulted in the addition of $19 \mathrm{~L}$ per container (Fig. 1C). Irrigation was not applied when rainfall exceeded $20 \mathrm{~mm}$ during a 24 -h period, which occurred three times during 2008 (Fig. 1C).

Daily water use was measured six times during the 2008 growing season. On the majority of measurement days, DWU was less than control irrigation with the exception of $B$. davidii 'Guinevere' (Fig. 5A-E). Daily water use of $B$. davidii 'Guinevere' tended to be higher than the other four species and exceeded the control on Days 12,31, 48, and 67 with DWU values of 34, 26, 22, and $28 \mathrm{~mm}$, respectively (Fig. 5A). Additionally, DWU exceeded the control on Day 67 for $S$. japonica 'Flaming Mound' and on Day 67 for $V$. nudum 'Bulk' with DWU of 25 and $20 \mathrm{~mm}$ per application (Fig. 5D-E). Daily water use peaked on Days 12 and 67 with the lowest DWU values tending to be on the first and last measurement days.

Average irrigation applied daily for the 100DWU, 100-75, and 100-75-75 treatments ranged from $6 \%$ to $42 \%, 18 \%$ to $50 \%$, and $22 \%$ to $52 \%$, respectively, less than the control depending on species with the exception of $B$. davidii 'Guinevere' (Table 2). Average DWU of $B$. davidii 'Guinevere' for the $100 \mathrm{DWU}, 100-75$, and $100-75-75$ treatments were $26 \%, 10 \%$, and $5 \%$, respectively, greater than the control (Table 2). For L. korolkowii 'Honey Rose', H. serrata 'Blue Billow', and V. nudum 'Bulk', average irrigation applied daily to the three DWU treatments was less than the control, and average irrigation applied to the 100-75 and $100-75-75$ treatments was less than the 100DWU treatment (Table 2). For $S$. japonica 'Flaming Mound', average irrigation applied to the 100-75 and 100-75-75 treatments were less than the 100DWU and control treatments (Table 2). Average irrigation applied to the $100-75,100-75-75$, and the control treatments were lower than the 100DWU treatment for $B$. davidii 'Guinevere' (Table 2). Average irrigation applied to 


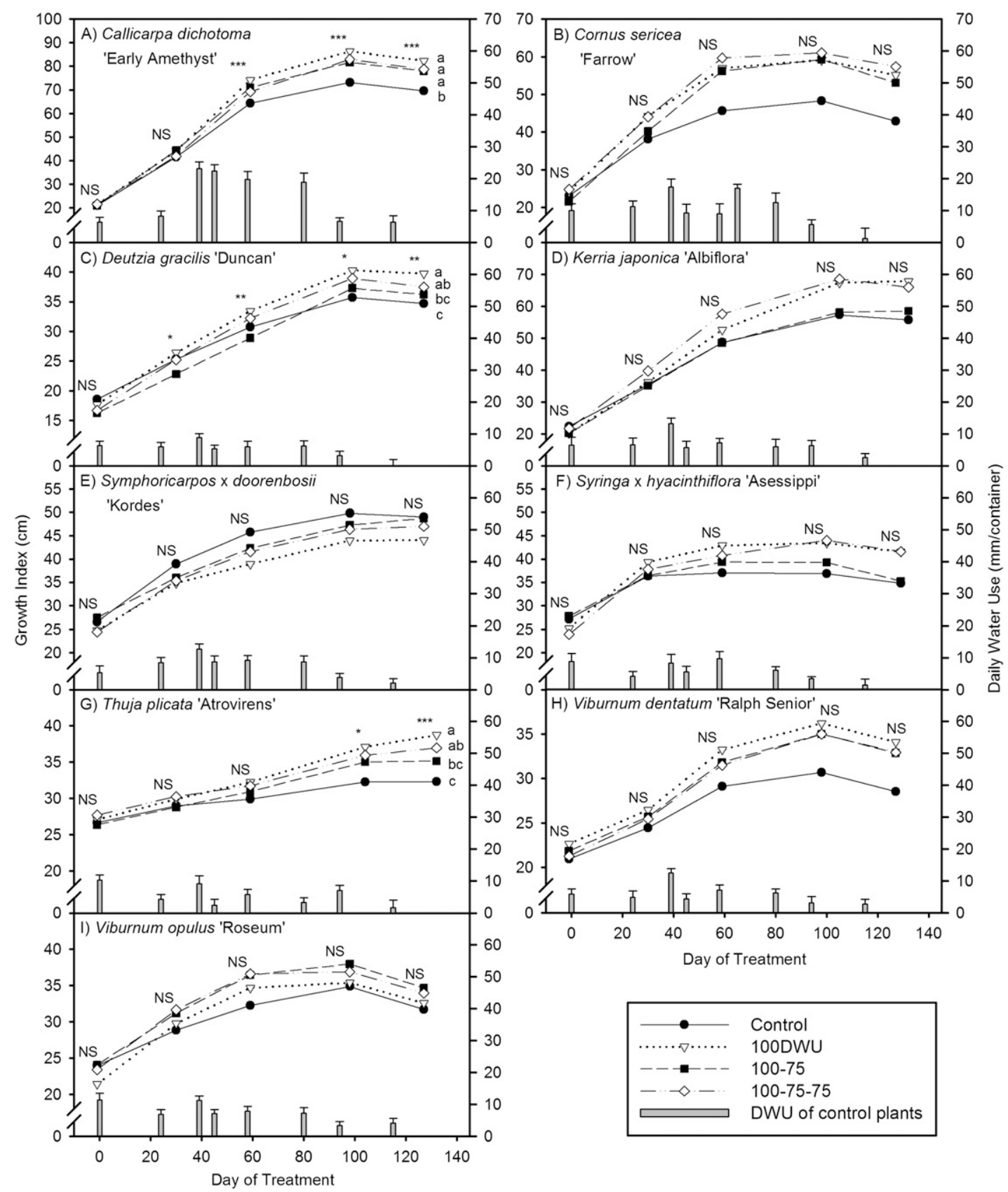

Fig. 2. Daily water use (bars $=$ DWU) of control plants and growth index (lines $=$ GI) of container-grown woody ornamentals under four irrigation treatments applied from 14 June to 13 Oct. 2006. Left y-axis corresponds to GI and scale varies depending on species. Right y-axis corresponds to DWU. Day $0=13$ June. Error bars for DWU correspond to the SE of the mean of DWU measurement of 18 plants of each species from the control treatment. Irrigation treatments: Control $=19 \mathrm{~mm}$ per application; $100 \mathrm{DWU}=100 \%$ daily water use (DWU) per application; $100-75=$ two-application cycle with $100 \%$ DWU first application and 75\% DWU second application; and 100-75-75 = three-application cycle 100\% DWU the first application followed by two applications of 75\% DWU Irrigation applications were separated by $\approx 24 \mathrm{~h}$. For each species, when significant at the 0.05 level, GI treatment means were separated on each day using a $t$ test. NS, ${ }^{*}, * * * * *$ Nonsignificant or significant at $P \leq 0.05,0.01$, or 0.001 , respectively. Means separation for final GI are shown when significant and for each species treatment means with the same letters are not significantly different. $\mathrm{n}=18$.

the $100-75$ and $100-75-75$ treatments was $12 \%$ and $17 \%$ lower, respectively, than the 100DWU treatment.

Water use classification. Low, moderate, and high water users in the current study correspond to $\mathrm{K}_{\mathrm{C}}<2,2 \leq \mathrm{K}_{\mathrm{C}}<3$, and $\mathrm{K}_{\mathrm{C}} \geq 3$, respectively. Crop coefficient values in the current study ranged from 1.6 to $3.8,1.6$ to 3.7 , and 3.1 to 6.8 in 2006, 2007, and 2008, respectively (Table 2). Cumulative $\mathrm{ET}_{\mathrm{P}}$ during the 2006, 2007, and 2008 experiments was $393.74 \mathrm{~mm}, 490.10 \mathrm{~mm}$, and $361.48 \mathrm{~mm}$, respectively.

Similar $\mathrm{K}_{\mathrm{C}}$ values ranging from less than 1 to 5.1 have been reported for other containergrown woody ornamentals (Burger et al., 1987; Niu et al., 2006; Schuch and Burger (1997). The wide range of reported $K_{C}$ values of container-grown plants is the result of a number of factors, including method used to calculate $\mathrm{ET}_{\mathrm{A}}$ and $\mathrm{ET}_{\mathrm{P}}$, seasonal fluctuations of $\mathrm{K}_{\mathrm{C}}$, plant growth stage, location (Schuch and Burger (1997), container spacing (Burger et al., 1987), and species (Niu et al., 2006).

Classifying plants into water use groups remains partially subjective because the specific variable(s) and the range of those variable(s) that determine water use class have yet to be formally defined. However, as water requirements of additional species are determined, the water use values that define a particular water use group should become clearer. As water use of more species are 


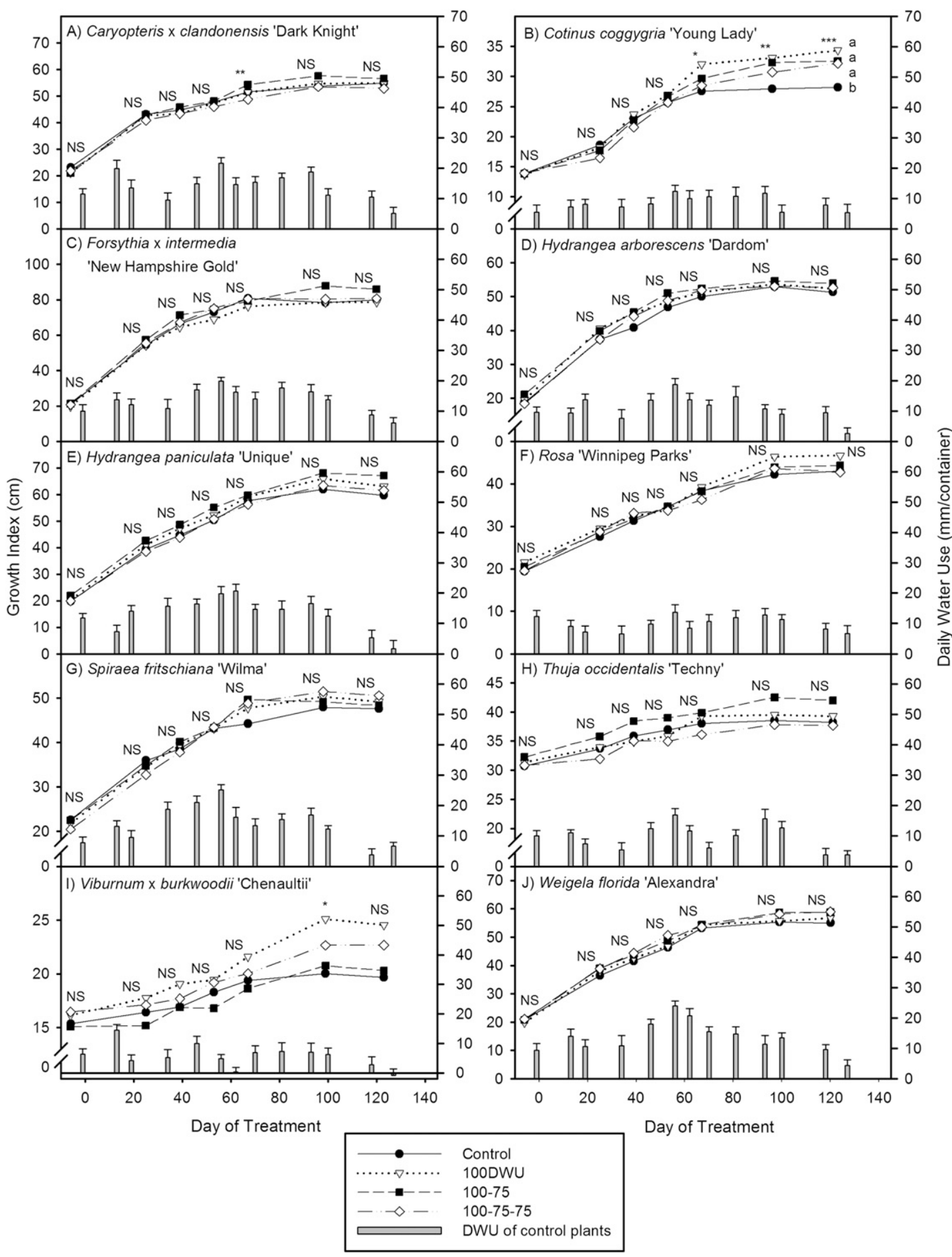

Fig. 3. Daily water use (bars $=$ DWU) of control plants and growth index (lines $=$ GI) of container-grown woody ornamentals under four irrigation treatments applied from 8 June to 13 Oct. 2007. Left y-axis corresponds to GI and scale varies depending on species. Right y-axis corresponds to DWU. Day $0=7$ June. Error bars for DWU correspond to the SE of the mean of DWU measurement of 18 plants of each species from the control treatment. Irrigation treatments: Control $=19 \mathrm{~mm}$ per application; 100DWU = 100\% daily water use (DWU) per application; $100-75=$ two-application cycle with $100 \%$ DWU first application and $75 \%$ DWU second application; and 100-75-75 = three-application cycle 100\% DWU the first application followed by two applications of $75 \%$ DWU. Irrigation applications were separated by $\approx 24 \mathrm{~h}$. For each species, when significant at the 0.05 level, GI treatment means were separated on each day using a $t$ test. NS, $* * *, * * *$ Nonsignificant or significant at $P \leq 0.05,0.01$, or 0.001 , respectively. Means separation for final GI are shown when significant and for each species treatment means with the same letters are not significantly different. $\mathrm{n}=18$.

determined, the $\mathrm{K}_{\mathrm{C}}$ ranges for each water use classification reported in this study may require adjustment, expansion, or division into additional water use classifications, i.e., more than three categories. Furthermore, water use fluctuates during the growing season as a result of changes in plant growth stage and environmental conditions. For example, daily DWU of $C$. dichotoma 'Early Amethyst' at $1 \mathrm{~d}$ after treatment initiation was $0.35 \mathrm{~L}$ per container but on Day 39 was $1.29 \mathrm{~L}$ per container (Fig. 2A). As a result, seasonal water use classifications may also be required. The classification of container-grown woody ornamentals as low, moderate, or high water users will improve the ability to group plants with similar water requirements together to conserve water. However, because water use varied among species within the same water use class, grouping and irrigating plants by water use class will not maximize the water 


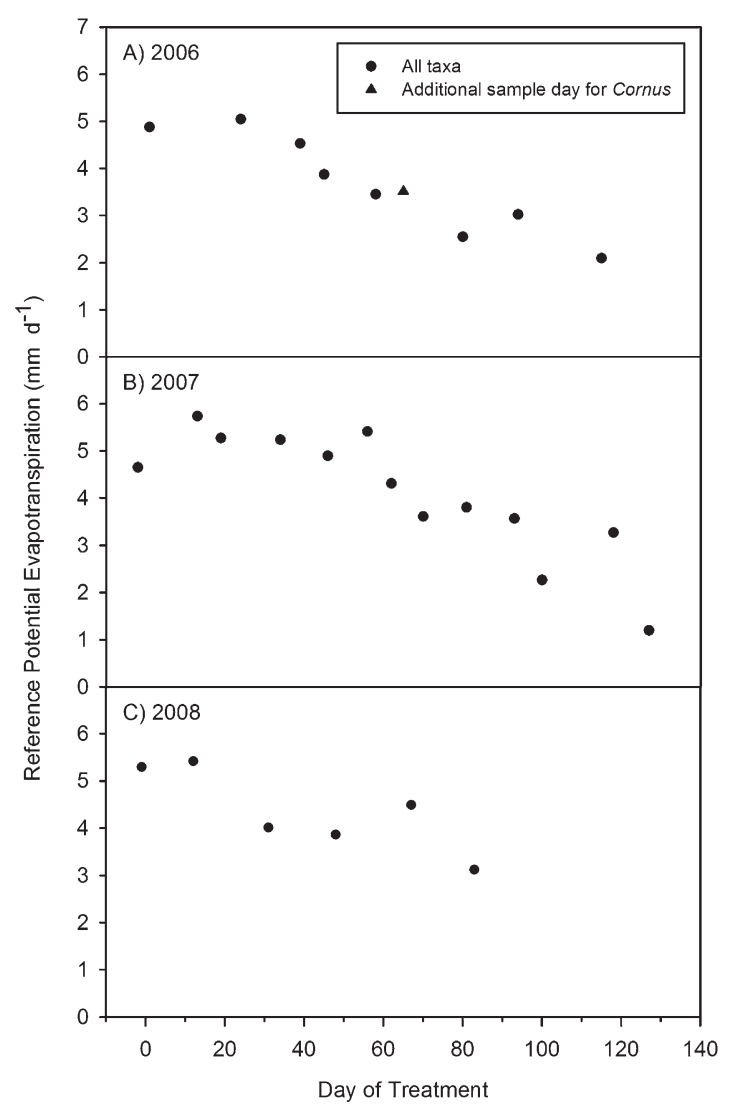

Fig. 4. Daily reference potential evapotranspiration $\left(\mathrm{ET}_{\mathrm{P}}\right)$ on days of plant daily water use measurement for (A) 2006, Day $0=14$ June; (B) 2007, Day $0=7$ June; and (C) 2008, Day $0=27$ June. Reference potential evapotranspiration estimated with the modified Penman method according to Kincaid and Heerman (1974). Data from a Michigan Automated Weather Network (MAWN) weather station at the Michigan State University Horticulture and Teaching Research Center. Data courtesy of Michigan State University and the Enviro-weather project.

conserving potential of DWU-based irrigation scheduling. To improve water conservation, $K_{C}$ values and DWU values should be published with water use classifications. Doing so would provide growers with additional information with which to make plant grouping decisions regarding species with similar water requirements.

Growth index: 2006. For all years, DWU treatments either increased or did not affect plant growth compared with the control for all species while conserving significant amounts of water. Irrigation treatment affected GI for only three of the nine species in 2006 (Fig. 2). For C. dichotoma 'Early Amethyst', GI of the control was lowest among treatments on Days 59, 100, and 127 (Fig. 2A). Lower GI of plants in the control treatment from Day 59 to the end of the experiment likely resulted from overwatering during the early and later parts of the growing season and underwatering during the middle part of the season when DWU was higher than the irrigation volume applied to the control (Fig. 2A). For D. gracilis 'Duncan', GI of the 100DWU and 100-75-75 treatments were greater than the control on Days 59, 99, and 127 (Fig. 2C). Differences in GI among treatments of $T$. plicata 'Atrovirens' did not occur until Day 105 when GI of the control was lowest among treatments, and final GI of the 100DWU and 100-75-75 treatments were greater than the control (Fig. 2G).

Plant GI for the majority of species increased steadily during the first $60 \mathrm{~d}$ of the experiment and then started to plateau. The reductions in GI for some taxa at the end of 2006 were the result of leaf senescence that occurred between the September and October measurements. Growth index of T. plicata 'Atrovirens', the only evergreen in the 2006 season, steadily increased throughout the experiment.

Growth index: 2007. Irrigation treatments affected GI of three of the 10 species in 2007 (Fig. 3). For C. ×clandonensis 'Dark Knight', GI of the 100-75 treatment was greater than the 100-75-75 treatment on Day 67 with no difference in final GI (Fig. 3A). Differences in GI among treatments of C. coggygria 'Young Lady' occurred on Days 67, 96, and 123 when GI of the control was lowest among treatments (Fig. 3B). For V. ×burkwoodii 'Chenaultii', GI of the 100DWU treatment was greater than the 100-75 and control treatments on Day 99 with no difference in final GI (Fig. 3I).

Plant growth of species grown in 2007 followed a similar pattern to species grown in 2006 with, for the majority of species, a steady increase in GI until approximately Day 60 before starting to plateau (Fig. 3A-J). Similar to T. plicata 'Atrovirens' in the 2006 experiment, GI of T. occidentalis 'Techny' increased throughout the experiment (Fig. 3H).

Growth index: 2008. Irrigation treatments did not affect the growth of any species during 2008 (Fig. 5A-E). B. davidii 'Guinevere' plants in all treatments exhibited rapid growth during the first $35 \mathrm{~d}$ of the study and were pruned back to a uniform height of 38 cm on Day 35 (1 Aug. 2008; Fig. 5A). Similar to patterns of growth for the majority of species grown in 2006 and 2007, growth in 2008 increased steadily to approximately Day 60 before starting to plateau. This period of steady growth generally coincided with the period of highest water use for the majority of species during each year of the study. Water use tended to decline during the second half of the experiment during each year as plant growth decreased or stopped.

Other studies have reported substantial reductions in irrigation with minimal to no effect on growth. Welsh et al. (1991) reported that Photina $\times$ fraseri irrigated with $100 \%$, $75 \%$, and $50 \%$ replacements of actual water use did not differ in water use, shoot extension, shoot dry weight, leaf number, average leaf area, and root area. Tyler et al. (1996) reported that a $44 \%$ reduction in irrigation volume resulted in top dry weight and total plant dry weight losses of $8 \%$ and $10 \%$ for Cotoneaster dammeri 'Skogholm'. Groves et al. (1998) reported similar results with a $40 \%$ reduction in irrigation volume resulting in the production of $90 \%$ dry weight of $C$. dammeri 'Skogholm', which was classified by the authors as having high water and medium nutrient requirements. These studies show that substantial reductions in irrigation are possible with little to no reductions in growth even when irrigation is applied at slight water deficits.

In 2006 and 2007, at least one of the three DWU irrigation treatments resulted in greater final GI compared with the control for the high water user $C$. dichotoma 'Early Amethyst', the moderate water user C. coggygria 'Young Lady', and the low water users D. gracilis 'Duncan' and T. plicata 'Atrovirens' (Figs. $2 \mathrm{~A}, \mathrm{C}$, and $\mathrm{G}$ and $3 \mathrm{~B}$ ). Average irrigation applied by the 100DWU treatment for these moderate and low water users was $56 \%$ to $70 \%$ less than the control. (Figs. 2 and 4). Fare et al. (1994) reported that $\mathrm{NO}_{3}-\mathrm{N}$ losses through leaching were $63 \%$ and $19 \%$ of total applied nitrogen at irrigation depths of 13 $\mathrm{mm}$ and $6 \mathrm{~mm}$. The lower final GI of control plants likely resulted from greater nutrient leaching under higher irrigation volumes of the control compared with DWU treatments. However, no nutrient deficiency symptoms were observed for these species. Average DWU of another low water user, $V$. dentatum 'Ralph Senior', was 69\% less than the control (Table 2), and although final GI was unaffected by irrigation volume, leaves of control plants were chlorotic by the end of the study indicating likely nutrient deficiencies.

In addition to reducing overwatering compared with a fixed irrigation rate, irrigating based on DWU ensures that adequate water 


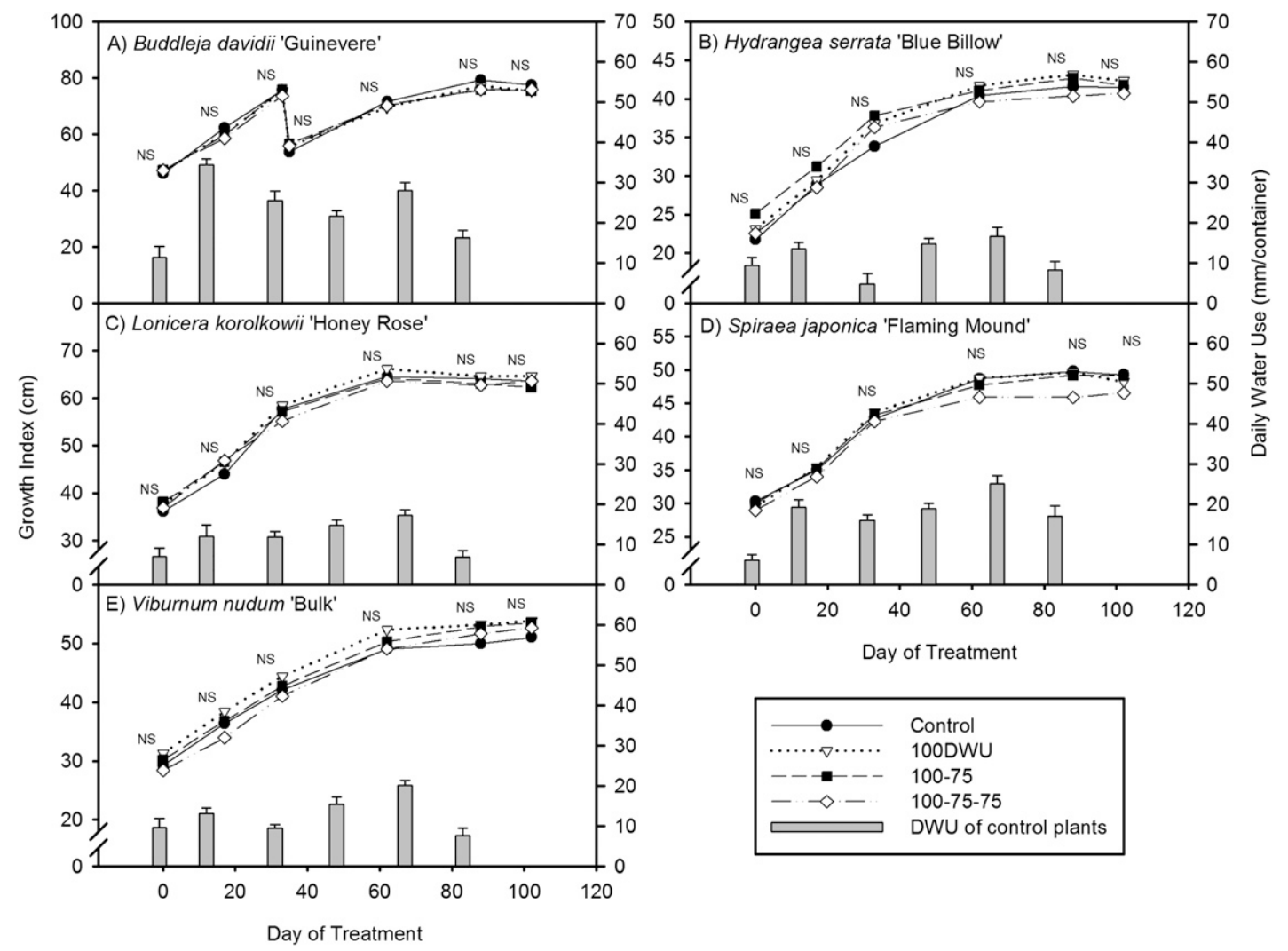

Fig. 5. Daily water use (bars $=\mathrm{DWU})$ of control plants and growth index (lines $=\mathrm{GI})$ of container-grown woody ornamentals under four irrigation treatments applied from 28 June to 10 Oct. 2008. Left y-axis corresponds to GI and scale varies depending on species. Right y-axis corresponds to DWU. Day $0=27$ June. Error bars for DWU correspond to the SE of the mean of DWU measurement of 18 plants of each species from the control treatment. Irrigation treatments: Control $=19 \mathrm{~mm}$ per application; 100DWU $=100 \%$ daily water use (DWU) per application; $100-75=$ two-application cycle with $100 \%$ DWU first application and 75\% DWU second application; and 100-75-75 = three-application cycle 100\% DWU the first application followed by two applications of 75\% DWU. Irrigation applications were separated by $\approx 24 \mathrm{~h}$. For each species, when significant at the 0.05 level, GI treatment means were separated on each day using a $t$ test. Ns, $*, * *, * * *$ Nonsignificant or significant at $P \leq 0.05,0.01$, or 0.001 , respectively. Means separation for final GI are shown when significant and for each species on treatment means with the same letters are not significantly different. $\mathrm{n}=18$.

is supplied to plants during periods of high water use. B. davidii 'Guinevere', $C$. dichotoma 'Early Amethyst', $C$. ×clandonensis 'Dark Knight', F. Xintermedia 'New Hampshire Gold', H. paniculata 'Unique', $S$. fritschiana 'Wilma', S. japonica 'Flaming Mound', V. nudum 'Bulk', and W. florida 'Alexandra' all had DWU values that exceeded the control on at least one measurement day during the experiment. During these periods, water applied by the control did not provide the DWU of these species. These data show that in addition to overwatering, a fixed irrigation schedule can result in underwatering with the potential to create water deficits in container substrate during extended periods of high water demand.

Beeson (2006) showed strong relationships between cumulative $\mathrm{ET}_{\mathrm{A}}$ and plant growth using different levels of managementallowed deficit irrigation (MAD). He concluded that restrictive irrigation regimens such as high MAD levels will lengthen production times by reducing the rate of plant growth, and the additional irrigation required during the extended period may exceed the irrigation applied by the less restrictive irrigation schedules. In the current experiment, GI increase of each species for each treatment was determined by regression analysis with the slope of the line corresponding to GI increase (data not presented). There was no evidence that irrigating according to the DWU treatments in the current study would increase production time because there was no affect of irrigation treatment on GI increase for any species, except T. plicata 'Atrovirens' in which GI increase of the 100DWU treatment was greater than the control $(P \leq 0.05)$.

Water use efficiency. Water use efficiency of at least one DWU treatment was improved compared with the control for all 24 taxa, except three in which there were no differences among treatments (Tables 3-5). This irrigation treatment effect was expected because irrigation applied to plants in the control treatment was usually in excess of plant DWU.

During 2006, WUE of the control was lowest among treatments for six of the nine species (Table 3). For C. sericea 'Farrow', WUE of the control was lower than the 100-75 and 100-75-75 treatments, and for $S$. ×hyacinthiflora 'Asessippi', WUE of the control treatment was lower than the 100 75-75 and 100DWU treatments (Table 3). There was no difference among treatments for $V$. opulus 'Roseum' (Table 3). In 2007, WUE of the control treatment was lowest among treatments for all species except T. occidentalis 'Techny' and V. ×burkwoodii 'Chenaultii' (Table 4). For T. occidentalis 'Techny' WUE of the 100-75 treatment was higher than the control, and for $V$. $\times$ burkwoodii 'Chenaultii', the 100DWU treatment had a higher WUE than the control. In 2008, WUE of the control was lowest among treatments for L. korolkowii 'Honey Rose', $V$. nudum 'Bulk', and $H$. serrata 'Blue Billow' (Table 5). For B. davidii 'Guinevere' and $S$. japonica 'Flaming Mound', irrigation treatment did not affect WUE (Table 5).

Among 2006 species, the high water user C. dichotoma 'Early Amethyst' used water the most efficiently in the control treatment (Table 3). The low water user, $K$. japonica 'Albiflora', was the most efficient water user among species in the 100DWU and 100-7575 treatments. $K$. japonica 'Albiflora' and $C$. dichotoma 'Early Amethyst' were the most efficient water users in the 100-75 treatment (Table 3). Among 2007 species, the high water user $F$. xintermedia 'New Hampshire Gold' was the most efficient water user in all treatments (Table 4). The two least efficient water users among species in all treatments were $T$. occidentalis 'Techny', a moderate water user, and $V$. $\times$ burkwoodii 'Chenaultii', a low water user (Table 4). 
Table 3. Estimated water use efficiency (WUE) of nine container-grown woody ornamentals under four irrigation regimes from 14 June to 13 Oct. 2006. ${ }^{z}$

\begin{tabular}{lllll}
\hline & \multicolumn{4}{c}{ Water use efficiency } \\
\cline { 2 - 5 } Species & Control $^{\mathrm{y}}$ & $100 \mathrm{DWU}$ & $100-75$ & $100-75-75$ \\
\hline Callicarpa dichotoma 'Early Amethyst' & $0.36 \mathrm{~b}^{\mathrm{x}} \mathrm{A}^{\mathrm{w}}$ & $0.59 \mathrm{aB}$ & $0.61 \mathrm{aA}$ & $0.64 \mathrm{aB}$ \\
Kerria japonica 'Albiflora' & $0.24 \mathrm{bB}$ & $0.79 \mathrm{aA}$ & $0.69 \mathrm{aA}$ & $0.82 \mathrm{aA}$ \\
Cornus sericea 'Farrow' & $0.16 \mathrm{bC}$ & $0.33 \mathrm{abDC}$ & $0.37 \mathrm{aBC}$ & $0.40 \mathrm{aC}$ \\
Symphoricarpos $\times$ doorenbosii 'Kordes' & $0.16 \mathrm{bC}$ & $0.30 \mathrm{aD}$ & $0.36 \mathrm{aBC}$ & $0.39 \mathrm{aC}$ \\
Deutzia gracilis 'Duncan' & $0.12 \mathrm{bCD}$ & $0.41 \mathrm{aD}$ & $0.40 \mathrm{aB}$ & $0.43 \mathrm{aC}$ \\
Syringa $\times$ hyacinthiflora 'Asessippi' & $0.06 \mathrm{cDE}$ & $0.27 \mathrm{abDE}$ & $0.13 \mathrm{bcD}$ & $0.32 \mathrm{aCD}$ \\
Viburnum dentatum 'Ralph Senior' & $0.06 \mathrm{bDE}$ & $0.21 \mathrm{aDE}$ & $0.22 \mathrm{aCD}$ & $0.24 \mathrm{aDE}$ \\
Viburnum opulus 'Roseum' & $0.06 \mathrm{aDE}$ & $0.17 \mathrm{aE}$ & $0.17 \mathrm{aD}$ & $0.18 \mathrm{aE}$ \\
Thuja plicata 'Atrovirens' & $0.04 \mathrm{bE}$ & $0.21 \mathrm{aDE}$ & $0.17 \mathrm{aD}$ & $0.19 \mathrm{aDE}$ \\
\hline
\end{tabular}

${ }^{2}$ Water use efficiency was estimated as increase in growth index (GI) per liter of total water applied. Total water applied included irrigation plus precipitation in liters per container.

${ }^{\mathrm{y}}$ Control $=19 \mathrm{~mm}$ per application; $100 \mathrm{DWU}=100 \%$ daily water use (DWU) per application; $100-75=$ two-application cycle with 100\% DWU first application and 75\% DWU the second application; 100-75-75 $=$ three-application cycle $100 \%$ DWU the first application followed by two applications of $75 \%$ DWU Irrigation applications were separated by $\approx 24 \mathrm{~h}$.

${ }^{x}$ Means with the same lowercase letters within the same row are not significantly different. Means separation by Tukey's test $(\alpha=0.05 ; \mathrm{n}=18)$.

${ }^{\text {w} M e a n s ~ w i t h ~ t h e ~ s a m e ~ u p p e r c a s e ~ l e t t e r s ~ w i t h i n ~ t h e ~ s a m e ~ c o l u m n ~ a r e ~ n o t ~ s i g n i f i c a n t l y ~ d i f f e r e n t . ~ M e a n s ~}$ separation by Tukey's Ttest $(\alpha=0.05 ; \mathrm{n}=18)$.

Table 4. Estimated water use efficiency (WUE) of 10 container-grown woody ornamentals under four irrigation regimes from 8 June to 13 Oct. $2007 .^{2}$

\begin{tabular}{lllll}
\hline & \multicolumn{4}{c}{ Water use efficiency } \\
\cline { 2 - 5 } Species & Control $^{\mathrm{y}}$ & $100 \mathrm{DWU}$ & $100-75$ & $100-75-75$ \\
\hline Forsythia $\times$ intermedia 'New Hampshire Gold' & $0.39 \mathrm{c}^{\mathrm{x}} \mathrm{A}^{\mathrm{w}}$ & $0.52 \mathrm{bA}$ & $0.63 \mathrm{aA}$ & $0.61 \mathrm{aA}$ \\
Hydrangea paniculata 'Unique' & $0.26 \mathrm{cB}$ & $0.37 \mathrm{bB}$ & $0.44 \mathrm{ab}$ & $0.42 \mathrm{ab}$ \\
Weigela florida 'Alexandra' & $0.22 \mathrm{cBC}$ & $0.32 \mathrm{bCB}$ & $0.37 \mathrm{abBC}$ & $0.39 \mathrm{aB}$ \\
Hydrangea arborescens 'Dardom' & $0.22 \mathrm{cC}$ & $0.33 \mathrm{bCB}$ & $0.37 \mathrm{abBC}$ & $0.41 \mathrm{aB}$ \\
Caryopteris $\times$ clandonensis 'Dark Knight' & $0.21 \mathrm{bC}$ & $0.29 \mathrm{aCD}$ & $0.34 \mathrm{aCD}$ & $0.31 \mathrm{aC}$ \\
Spiraea fritschiana 'Wilma' & $0.16 \mathrm{bD}$ & $0.24 \mathrm{aD}$ & $0.25 \mathrm{aE}$ & $0.31 \mathrm{aC}$ \\
Rosa 'Winnipeg Parks' & $0.15 \mathrm{bD}$ & $0.28 \mathrm{aCD}$ & $0.30 \mathrm{aCDE}$ & $0.30 \mathrm{aC}$ \\
Cotinus coggygria 'Young Lady' & $0.09 \mathrm{bE}$ & $0.27 \mathrm{aCD}$ & $0.27 \mathrm{aDE}$ & $0.28 \mathrm{aC}$ \\
Thuja occidentalis 'Techny' & $0.05 \mathrm{bF}$ & $0.09 \mathrm{abE}$ & $0.12 \mathrm{aF}$ & $0.09 \mathrm{abD}$ \\
Viburnum $\times$ burkwoodii 'Chenaultii' & $0.03 \mathrm{bF}$ & $0.14 \mathrm{aE}$ & $0.10 \mathrm{abF}$ & $0.12 \mathrm{abD}$ \\
\hline
\end{tabular}

${ }^{\mathrm{z}}$ WUE was estimated as increase in growth index (GI) per liter of total water applied. Total water applied included irrigation plus precipitation in liters per container.

${ }^{\mathrm{y}} \mathrm{Control}=19 \mathrm{~mm}$ per application; 100DWU $=100 \%$ daily water use (DWU) per application; $100-75=$ two-application cycle with 100\% DWU first application and 75\% DWU second application; 100-75-75 = three-application cycle $100 \%$ DWU the first application followed by two applications of $75 \%$ DWU. Irrigation applications were separated by $\approx 24 \mathrm{~h}$.

${ }^{x}$ Means with the same lowercase letters within the same row are not significantly different. Means separation by Tukey's test $(\alpha=0.05 ; \mathrm{n}=18)$.

${ }^{\text {w} M e a n s ~ w i t h ~ t h e ~ s a m e ~ u p p e r c a s e ~ l e t t e r s ~ w i t h i n ~ t h e ~ s a m e ~ c o l u m n ~ a r e ~ n o t ~ s i g n i f i c a n t l y ~ d i f f e r e n t . ~ M e a n s ~}$ separation by Tukey's test $(\alpha=0.05 ; \mathrm{n}=18)$.

Table 5. Estimated water use efficiency (WUE) of five container-grown woody ornamentals under four irrigation regimes from 28 June to 7 Oct. $2008 .^{2}$

\begin{tabular}{llccc}
\hline & \multicolumn{4}{c}{ Water use efficiency } \\
\cline { 2 - 5 } Species & Control $^{\mathrm{y}}$ & $100 \mathrm{DWU}$ & $100-75$ & $100-75-75$ \\
\hline Buddleja davidii 'Guinevere' & $0.42 \mathrm{a}^{\mathrm{x}} \mathrm{A}^{\mathrm{w}}$ & $0.31 \mathrm{aA}$ & $0.34 \mathrm{aA}$ & $0.35 \mathrm{aA}$ \\
Lonicera korolkowii 'Honey Rose' & $0.21 \mathrm{bB}$ & $0.31 \mathrm{aA}$ & $0.31 \mathrm{aA}$ & $0.36 \mathrm{aA}$ \\
Viburnum nudum 'Bulk' & $0.17 \mathrm{bBC}$ & $0.25 \mathrm{aB}$ & $0.29 \mathrm{aA}$ & $0.32 \mathrm{aAB}$ \\
Hydrangea serrata 'Blue Billow' & $0.16 \mathrm{bC}$ & $0.24 \mathrm{aB}$ & $0.23 \mathrm{aB}$ & $0.26 \mathrm{aB}$ \\
Spiraea japonica 'Flaming Mound' & $0.15 \mathrm{aC}$ & $0.16 \mathrm{aC}$ & $0.18 \mathrm{aB}$ & $0.17 \mathrm{aC}$ \\
\hline
\end{tabular}

${ }^{2}$ WUE was estimated as increase in growth index (GI) per liter of total water applied. Total water applied included irrigation plus precipitation in liters per container.

${ }^{\mathrm{y}} \mathrm{Control}=19 \mathrm{~mm}$ per application; 100DWU $=100 \%$ daily water use (DWU) per application; 100-75 = two-application cycle with 100\% DWU first application and 75\% DWU second application; 100-75-75 = three-application cycle $100 \%$ DWU the first application followed by two applications of $75 \%$ DWU. Irrigation applications were separated by $\approx 24 \mathrm{~h}$.

${ }^{x}$ Means with the same lowercase letters within the same row are not significantly different. Means separation by Tukey's test $(\alpha=0.05 ; \mathrm{n}=18)$.

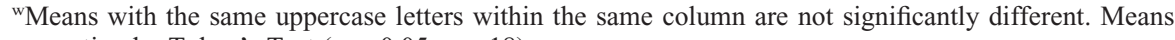
separation by Tukey's Test $(\alpha=0.05 ; \mathrm{n}=18)$.

Among 2008 species, all high water users, B. davidii 'Guinevere' was the most efficient water user in the control treatment (Table 5).
For the 100DWU treatment $B$. davidii 'Guinevere' and L. korolkowii 'Honey Rose' had the highest WUE values among species and $S$. japonica 'Flaming Mound' the lowest (Table 5). For the 100-75 and 100-75-75 treatments, WUE of B. davidii 'Guinevere', L. korolkowii 'Honey Rose', and V. nudum 'Bulk' were higher than S. japonica 'Flaming Mound'.

B. davidii 'Guinevere' was the only taxon during the three growing seasons in which average irrigation applied to the control treatment during the experiment was less than the 100DWU treatment and not different from the 100-75 and 100-75-75 treatments (Table 2). On days with high evaporative demand, the control was a deficit treatment similar to the 100-75 and 100-75-75 treatments. Although water applied by the control averaged $21 \%$ less than the $100 \mathrm{DWU}$ treatment, there were no differences in GI, GI increase, or WUE. This suggests that irrigation can be reduced further. Although mild flagging of new growth occurred in all treatments during the afternoon on several hot dry days during late July and August, plants recovered the next day after irrigation. Flagging of control plants was likely caused by irrigation failing to meet plant water requirements on days of high evaporative demand. Flagging in DWU treatments occurred several days after the DWU measurement day used to schedule irrigation for that period. Increasing leaf area in the days after DWU measurement and high evaporative demand likely caused evapotranspiration to exceed the scheduled DWU amount resulting in flagging. Flagging only occurred for $B$. davidii 'Guinevere' and was an indication to update DWU values used for scheduling DWU treatment irrigation.

Because there were no differences in GI increase among treatments for any species during the experiment, except for T. plicata 'Atrovirens' in 2006, differences in WUE were primarily affected by differences in total water applied. F. xintermedia 'New Hampshire Gold', H. arborescens 'Dardom', $H$. paniculata 'Unique', and $W$. florida 'Wilma' had higher WUE values at lower irrigation treatments with no differences in GI or GI increase. These species produced the same amount of growth from less applied water. Therefore, it may be possible to further reduce irrigation applications before affecting growth. Tyler et al. (1996) reported irrigation use efficiency of Cotoneaster dammeri 'Skogholm' grown under a low leaching fraction (LF) of 0.0 to 0.2 was $29 \%$ higher than a high LF of 0.4 to 0.6 . These results support the higher WUE values of the DWU treatments compared with the control for the majority of species in the current study. In addition, irrigation reductions may be possible for other taxa as well, because final GI of the most restrictive DWU treatment (100-7575) did not differ from the 100DWU treatment for any taxa during the three growing seasons (Figs. 2-4).

Water use efficiency among species varied within each water use classification for the 100DWU treatment. K. japonica 'Albiflora' was in the low water use group and had a WUE of 0.79 (Table 4). In contrast, WUE of another low water user, $V$. ×burkwoodii 
'Chenaultii', was only 0.14 (Table 5). The wide range of WUE estimates reported within a water use group is supported by Still and Davies (1993) who reported different WUE values among species in the same water use classifications.

Still and Davies (1993) reported that growers tended to correlate water use of container-grown ornamentals with plant size. In the current study, DWU and GI were not statistically compared among species. However, some species with a large GI such as $C$. dichotoma 'Early Amethyst', F. Xintermedia 'New Hampshire Gold', and B. davidii 'Guinevere' also had a high DWU and some species with a low GI such as $V$. dentatum 'Ralph Senior' and $V$. ×burkwoodii 'Chenaultii' had a low DWU (Figs. 2, 3, and 5). Although plant size has been shown to influence water use (Knox, 1989), scheduling irrigation based on plant size alone can lead to over- or underwatering. Still and Davies (1993) reported that Ligustrum japonicum was rated as a heavy water user by producers before the experiment but was among the lowest of the eight species in the study in total water consumption and WUE. Results similar to those of Still and Davies (1993) could be expected if plants in the current study had been assigned a water use group based on plant size alone. In the 100DWU treatment, H. paniculata 'Unique' and $K$. japonica 'Albiflora' had mean final growth indices of $63 \mathrm{~cm}$ and $68 \mathrm{~cm}$, but $H$. paniculata 'Unique', a high water user with a WUE of 0.37 , used more than twice as much water as $K$. japonica 'Albiflora', a low water user with a WUE of 0.79 (Tables 2-4; Figs. 2 and 3). Although these two species were grown during different growing seasons, this shows that the water use between species of similar-sized potted plants can vary dramatically. These examples stress the importance of using actual water use data for irrigation scheduling instead of perceived water use based on plant size alone.

Electrical conductivity. Electrical conductivity and $\mathrm{pH}$ of irrigation water in September of 2007 was $0.70 \mathrm{dS} \cdot \mathrm{m}^{-1}$ and 7.7, respectively. High initial EC values in June were likely a result of substrate drying and subsequent buildup of soluble salts during the winter when irrigation was not applied and limited plant uptake in May and early June as a result of small plant size (Fig. 6A-C). On Day 48, EC of the control treatment was highest among treatments for $H$. arborescens 'Dardom', and on Day 106, EC of the control and 100DWU treatments were higher than the 100-75 and 100-75-75 treatments (Fig. $6 \mathrm{~A})$. Leachate EC of the 100DWU and 10075-75 treatments were higher than the control for $V$. ×burkwoodii 'Chenaultii' on Day 14 with no other differences (Fig. 6C).

A concern when scheduling irrigation at or below DWU is that leaching fractions will be close to or below zero and may cause EC levels to increase to above recommended levels if precipitation or a periodic increase in irrigation to flush excess salts from the substrate does not occur. Recommended levels of EC when using the PourThru technique
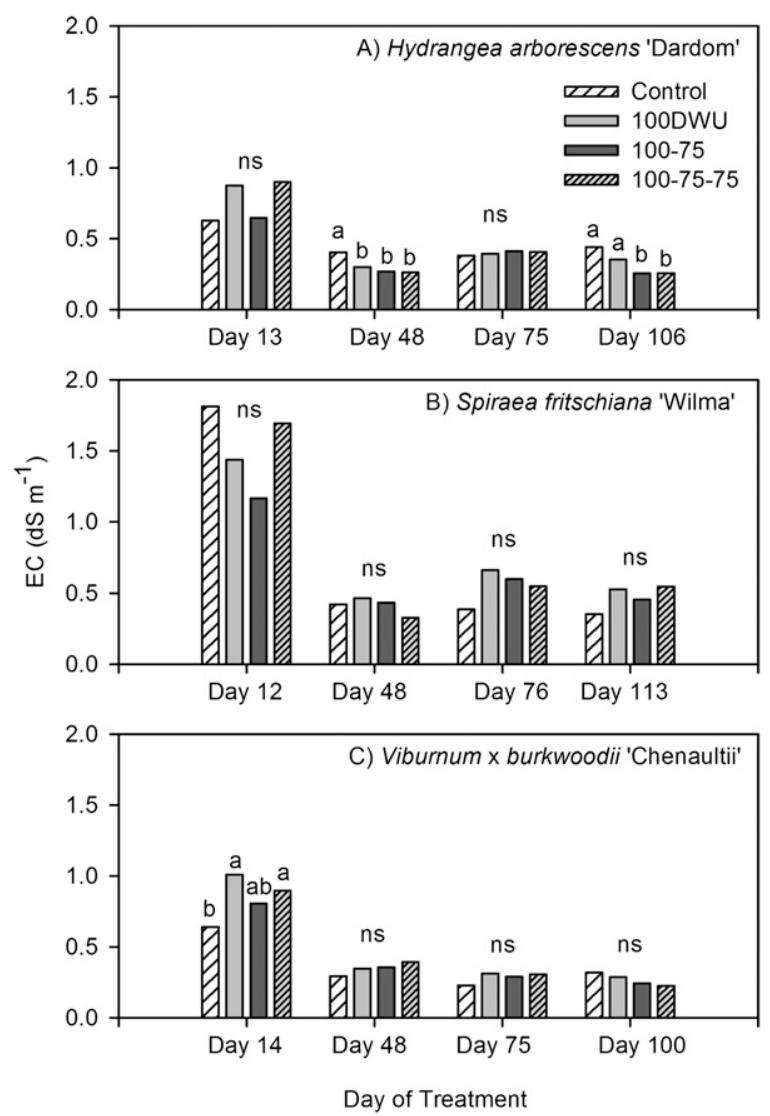

Fig. 6. Leachate electrical conductivity (EC) of three species of container-grown woody ornamentals under four irrigation treatments on $4 \mathrm{~d}$ during 2007. Within each day treatment means followed by the same letter are not significantly different ( $t$ test, $\alpha=0.05$ ). NS $=$ No significant difference between treatments. $\mathrm{n}=18$. Control $=19 \mathrm{~mm}$ per application; $100 \mathrm{DWU}=100 \%$ daily water use (DWU) per application; $100-75=$ two-application cycle with $100 \%$ DWU first application and $75 \%$ DWU second application; and $100-75-75=$ three-application cycle $100 \%$ DWU the first application followed by two applications of $75 \%$ DWU. Irrigation applications were separated by $\approx 24 \mathrm{~h}$.

for container-grown plants in pine bark substrates fertilized with only a CRF should range from 0.2 to $0.5 \mathrm{dS} \cdot \mathrm{m}^{-1}$ (Southern Nursery Association, 2007). Although there were differences in EC levels among treatments on Days 48 and 106 for $H$. arborescens 'Dardom', EC levels of all treatments were within the recommended range of 0.2 to $0.5 \mathrm{dS} \cdot \mathrm{m}^{-1}$ (Fig. 6A). Furthermore, during a 38-d period in which only $12.5 \mathrm{~mm}$ of precipitation occurred and the largest precipitation event was $3.6 \mathrm{~mm}$, EC values of the three DWU treatments for the three species were not above the recommended range and were not higher than the control treatment. Although soluble salt accumulation did not occur in this experiment, it is suggested that EC be monitored when irrigation is applied at rates resulting in low leaching fractions because higher fertilizer rates than used in this study or other conditions may result in EC buildup. In the event that elevated soluble salt concentrations become a concern, growers can periodically increase irrigation volume to flush excess soluble salts from the substrate.

\section{Conclusions}

Scheduling irrigation based on DWU conserved water for all species, except $B$. davidii
'Guinevere' and the 100DWU treatment of $S$. japonica 'Flaming Mound', compared with $19 \mathrm{~mm}$ per application while improving or not affecting plant growth. Water volume applied from DWU treatments was $6 \%$ to $75 \%$ less than the control depending on treatment and species. Species were classified as low, moderate, and high water users based on estimated $\mathrm{K}_{\mathrm{C}}$ values with six low, five moderate, and 13 high water users in the study. These classifications allow species with similar water requirements to be grouped together to reduce overwatering.

Final GI of DWU treatments of all species were greater or equal to the control treatment. Greater nutrient losses from container substrates resulting from higher irrigation volumes have been documented by Tyler et al. (1996) and Warsaw et al. (unpublished data). Leaching of nutrients caused by irrigation volumes in excess of DWU would explain growth reductions that occurred in this study for plants in the control treatment.

The decision on which DWU treatment should be used to schedule irrigation depends on a number of factors. The ideal irrigation regimen should provide the most economical balance between crop returns and water management concerns, which ultimately will vary with crop, water availability, regulations, and 
location (Welsh and Zajicek, 1993). Additionally, the cost of water, type of irrigation system, and programming capabilities of the system will partially dictate the irrigation regimen used. For example, a nursery in close proximity to a large urban area in a state where water use and runoff are highly regulated may elect to irrigate at a slight deficit using either the $100-75$ or $100-75-75$ irrigation schedules to minimize water extraction and runoff. The goal of water-conserving irrigation scheduling is to base irrigation applications on plant demand and to group plants with similar water uses together. Scheduling irrigation according to plant DWU substantially reduced the amount of irrigation applied compared with a control for 23 of the 24 species of container-grown ornamentals evaluated in this experiment while producing larger or the same sized plants for all species. In addition, further reductions in irrigation applications may be possible because the final GI between the 100DWU and 100-75-75 treatments did not differ for any species. Furthermore, the assignment of these species into water use groups by $\mathrm{K}_{\mathrm{c}}$ values along with reported average DWU will improve grower ability to group plants with similar water uses together.

\section{Literature Cited}

Beeson, R.C., Jr. 2006. Relationship of plant growth and actual evapotranspiration to irrigation frequency based on management allowed deficits for container nursery stock. J. Amer. Soc. Hort. Sci. 131:140-148.

Beeson, R.C., Jr., M.A. Arnold, T.E. Bilderback, B. Bolusky, S. Chandler, H.M. Gramling, J.D. LeaCox, J.R. Harris, P.J. Klinger, H.M. Mathers, J.M. Ruter, and T.H. Yeager. 2004. Strategic vision of container nursery irrigation in the next ten years. J. Environ. Hort. 22:113-115.
Bilderback, T.E. 2001. Using the PourThru procedure for checking the $\mathrm{EC}$ and $\mathrm{pH}$ for nursery crops. Horticulture Information Leaflet-401, North Carolina State University, North Carolina Cooperative Extension Service.

Burger, D.W., J.S. Hartin, D.R. Hodel, T.A. Lukaszewski, S.A. Tjosvold, and S.A. Wagner. 1987. Water use in California's ornamental nurseries. Calif. Agr. 41:7-8.

Cornejo, C., D.Z. Haman, and T.H. Yeager. 2005. Evaluation of soil moisture sensors, and their use to control irrigation systems for containers in the nursery industry. ASAE Meeting Paper No. 054056. ASAE, St. Joseph, MI.

Delta-Devices Ltd. 1999. ThetaProbe soil moisture sensor. User Manual ML2-UM-1.21. Delta-T Devices Ltd., Cambridge, UK.

Dooenbos, J. and W.O. Pruitt. 1975. Guidelines for prediction of crop water requirements. FAO Irrig. and Drain. Paper No. 24. Rome, Italy.

Fare, D.C., C.G. Gilliam, and G.J. Keever. 1992. Monitoring irrigation at container nurseries. HortTechnology 2:75-78.

Fare, D.C., C.H. Gilliam, G.J. Keever, and J.W Olive. 1994. Cyclic irrigation reduces container nitrate-nitrogen concentration. HortScience 29:1514-1517.

Garcia y Garcia, A., G. Hoogenboom, and L. Guerra. 2004. Container temperature and moisture for estimating evapotranspiration of nursery crops. ASAE/CSAE Meeting Paper No. 042295. ASAE, St. Joseph, MI.

Groves, K.M., S.L. Warren, and T.E. Bilderback. 1998. Irrigation volume, application, and controlled-release fertilizers: I. Effect on plant growth and mineral nutrient content in containerized plant production. J. Environ. Hort. 16: 176-181.

Kincaid, D.C. and D.F. Heerman. 1974. Scheduling irrigations using a programmable calculator. USDA-ARS-NC-12. US Govt. Printing Office, Washington, DC.

Knox, G.W. 1989. Water use and average growth index of five species of container-grown woody landscape plants. J. Environ. Hort. 7:136-139.
Michigan Department of Agriculture. 2009. Generally accepted agricultural management practices for irrigation water use. Michigan Department of Agriculture, Lansing, MI. 5 Mar. 2009. <http://www.michigan.gov/documents/ MDA_Irrigation_GAAMP_129710_7.pdf>.

Niu, G., D.S. Rodriguez, R. Cabrera, C. McKenney, and W. Mackay. 2006. Determining water use and crop coefficients of five woody landscape plants. J. Environ. Hort. 24:160-165.

Schuch, U.K. and D.W. Burger. 1997. Water use and crop coefficients of woody ornamentals in containers. J. Amer. Soc. Hort. Sci. 122:727734.

Southern Nursery Association. 2007. Best management practices: Guide for producing nursery crops. 2nd Ed. Southern Nursery Association, Atlanta, GA.

Still, D.W. and F.T. Davies, Jr. 1993. Water use, water use efficiency and growth analysis of selected woody ornamental species under a nonlimiting water regime. Scientia Hort. 53:213-223.

Tyler, H.H., S.L. Warren, and T.E. Bilderback. 1996. Reduced leaching fractions improve irrigation use efficiency and nutrient efficacy. J. Environ. Hort. 14:199-204.

Weatherspoon, D.M. and C.C. Harrell. 1980. Evaluation of drip irrigation for container production of woody landscape plants. HortScience $15: 488-489$

Welsh, D.F. and J.M. Zajicek. 1993. A model for irrigation scheduling in container-grown nursery crops utilizing management allowed deficit (MAD). J. Environ. Hort. 11:115-118.

Welsh, D.F., J.M. Zajicek, and C.G. Lyons, Jr. 1991. Effect of seasons and irrigation regimes on plant growth and water-use of container-grown Photina $\times$ fraseri. J. Environ. Hort. 9:79-82.

Yeager, T.H. 2003. Implementation guide for container-grown plant interim Measure. EDIS Document ENH-895. Environmental Horticulture Department, Florida Cooperative Extension Service, Institute of Food and Agricultural Sciences, University of Florida. 23 Jan. 2008. $<$ http://edis.ifas.ufl.edu/EP152>. 